\title{
The absence of high-risk human papillomavirus in Czech non-small cell lung cancer cases
}

\author{
Hana Jaworek, Vladimira Koudelakova, Rastislav Slavkovsky, Jiri Drabek, Marian Hajduch
}

\begin{abstract}
Aims. The purpose of our study was to examine the presence of human papillomavirus (HPV) DNA in Czech patients with non-small cell lung cancer (NSCLC).

Methods. A highly sensitive quantitative polymerase chain reaction (qPCR) detecting the E6 gene of HPV16, 18, 31, and 56 was designed. The limit of detection was assessed using serial dilutions of HPV-positive plasmids. The qPCR was validated on a set of 402 cervical swabs where the GPCR, Cobas, and PapilloCheck methods were tested in parallel. Finally, qPCR was used for HPV detection in a set of 80 patients with primary NSCLC, both from formalin-fixed paraffinembedded (FFPE) and fresh frozen (FF) tissue samples.

Results. The qPCR method was able to reliably detect at least 4 copies of the E6 gene per reaction in HPV16, 18, and 31 , and 40 copies per reaction in HPV56. The sensitivity and specificity of the qPCR were $75.6-99.3 \%$ and $63.9-100 \%$ respectively, depending on the HPV genotype and reference method used. HPV DNA was not detected in the FFPE and FF samples from the set of 80 NSCLC patients.
\end{abstract}

Conclusion. No hrHPV DNA was found in primary NSCLC tumors from a Czech population.

Key words: human papillomavirus, non-small cell lung cancer, PCR, HPV16, HPV18

Received: August 23, 2018; Accepted: December 11, 2018; Available online: January 10, 2019

https://doi.org/10.5507/bp.2018.079

(c) 2020 The Authors; https://creativecommons.org/licenses/by/4.0/

Institute of Molecular and Translational Medicine, Faculty of Medicine and Dentistry, Palacky University Olomouc, Hnevotinska 1333/5, 77900 Olomouc, Czech Republic

Corresponding author: Vladimira Koudelakova, e-mail: vladimira.koudelakova@upol.cz

\section{INTRODUCTION}

Lung cancer is the leading cause of cancer-related mortality worldwide. The pathogenesis of lung cancer is a complex interaction between environmental and genetic factors. Exposure to tobacco smoke (active or passive), radiation, radon, asbestos, hard metals, indoor/outdoor air pollution and genetics were identified as main etiologic factors for lung cancer development ${ }^{1}$. However, several viral infections were identified as human carcinogens, including the human papillomavirus (HPV) infection ${ }^{2}$. The carcinogenic role of high-risk (hr) HPV infection has been demonstrated in almost all cervical carcinomas, and in a subset of oropharyngeal and anogenital (penile, vaginal, vulvar, and anal) cancers ${ }^{3}$.

The respiratory tract is located close to the oropharynx, where HPV is a known causal agent of a subset of cancers ${ }^{4}$. Moreover, the HPV infection is the causal agent of benign respiratory papillomas that occasionally progress to malignancy ${ }^{5,6}$. In addition, lung tumors have morphological similarities to anogenital cancers caused by HPV $\left(\right.$ ref. $\left.^{7.8}\right)$. These facts led to the hypothesis that here is an association between HPV infection and lung cancer. Several studies have examined the impact of the HPV infection on lung cancer development, including large meta-analyses, but with conflicting results ${ }^{9-13}$.

HPV prevalence, as reported in these studies, ranged from $0 \%$ to $78 \%$ and showed extreme geographical vari- ability ${ }^{13}$. HPV prevalence was significantly higher in South American and Asian studies compared to European ones $^{12}$. The presence of $E 6 / E 7 \mathrm{mRNA}$ is the most informative for recognizing biologically-relevant HPV infection. A recent, large Central European study found no active HPV infections in its samples even though the samples were $10 \%$ positive for HPV DNA (ref. ${ }^{14}$ ).

While several studies have shown the presence of HPV in lung cancer, the causative role of HPV in lung carcinogenesis remains unclear. The objective of this study was to determine HPV prevalence in NSCLC in the Czech Republic, and its potential clinical significance.

\section{MATERIAL AND METHODS}

\section{Plasmids containing HPV DNA}

Plasmids containing HPV16 (pHPV16 purified plasmid DNA, ATCC ${ }^{\circledR} 45113 \mathrm{D}^{\mathrm{TM}}$ ), HPV18 (HPV18 purified plasmid DNA, ATCC ${ }^{\circledR} 45152 \mathrm{D}^{\mathrm{TM}}$ ), and HPV56 (HPV56 clone 2C purified plasmid DNA, ATCC ${ }^{\circledR}$ $40549^{\mathrm{TM}}$ ) genomes were purchased from ATCC (Rockville, MD); these plasmids were used to determine the limit of detection (LOD) of the quantitative polymerase chain reaction (qPCR) method developed for this study. Plasmids containing HPV31 genome were kindly provided by L.A. Laimins (Northwestern University, Feinberg School of Medicine, Chicago, USA). Serial di- 
lutions of 4, 40, 400, 4000, 40000, and 400000 copies of HPV genome per reaction were prepared from the plasmid DNA to generate standard curves by plotting DNA concentrations against cycle threshold values $\left(\mathrm{C}_{\mathrm{T}}\right)$.

\section{Clinical specimen collection}

The qPCR method was validated using a set of 402 cervical swabs which were collected in cobas ${ }^{\circledR}$ PCR Cell Collection media (Roche Diagnostics, Mannheim, Germany) and stored and transported at room temperature. Next, the qPCR was used to determine the presence of HPV in a cohort of 80 patients who had experienced radical surgical resection of primary NSCLC between 2009 and 2013. Histology slides were reviewed for classification, grading, and pathological staging. Surgical resection was considered the primary treatment method for all cases with $(n=42)$ or without $(n=38)$ adjuvant therapy. No patients had prior tumor diagnoses. Table 1 summarizes the clinicopathological characteristics of the patient cohort in this investigation.

\section{DNA Extraction and BRAF, KRAS, EGFR mutation analysis}

DNA from the cervical samples of the validation set was isolated using cobas x 480 and analyzed using the cobas $^{\circledR} 4800$ HPV Test (Roche Diagnostics, Mannheim, Germany), PapilloCheck ${ }^{\circledR}$ HPV-Screening (Greiner BioOne, Frickenhausen, Germany), and the HPV16, 18, 31, 56 qPCR in parallel.

DNA from formalin-fixed paraffin-embedded (FFPE) and fresh frozen (FF) tissue from the same NSCLC tumor sample was isolated using a cobas ${ }^{\circledR}$ DNA Sample Preparation Kit (Roche Diagnostics, Mannheim, Germany), according to manufacturer's instructions.

DNA isolated from FFPE tissue was subjected to further testing to determine the presence of $K R A S, E G F R$, and $B R A F$ mutations. Tests for the $B R A F$ mutation in all FFPE samples were conducted using the BRAF p.Val600Glu kit (IntellMed, Olomouc, Czech Republic). The Cobas ${ }^{\circledR}$ EGFR Mutation Test (Roche Diagnostics GmBH, Mannheim, Germany) was used to detect EGFR mutations. The TheraScreen ${ }^{\circledR}$ : K-RAS Mutation Kit (Roche Diagnostics GmBH, Mannheim, Germany) was used to detect KRAS mutations. All detection methods used were performed according to the manufacturer's recommendations.

\section{HPV DNA detection}

DNA of the HPV16, 18, 31, and 56 was detected using type-specific multiplex qPCR simultaneously detecting the E6 HPV gene and the human GAPDH (glyceraldehyde-3-phosphate dehydrogenase) gene. The qPCR was performed with $2 \mu \mathrm{L}$ of total DNA, Thermo-Start DNA polymerase (ThermoScientific, Waltham, MA), and the PCR primers and probes listed in Table 2 using Light Cycler ${ }^{\circledR} 480$ II (Roche Diagnostics, Mannheim, Germany). The qPCR conditions consisted of $95^{\circ} \mathrm{C}$ for $15 \mathrm{~min}$, followed by 45 cycles of $95^{\circ} \mathrm{C}$ for $15 \mathrm{~s}$ and $60{ }^{\circ} \mathrm{C}$ for 60 s. LightCycler ${ }^{\circledR} 480$ software (Roche Diagnostics, Mannheim, Germany) was used for data evaluation. A
Table 1. Clinicopathological characterization of 80 patients with primary non-small cell lung cancer.

\begin{tabular}{|c|c|c|}
\hline \multicolumn{2}{|l|}{ Characteristic } & \multirow{2}{*}{$\frac{n(\%)}{26(32.5 \%)}$} \\
\hline Sex & Female & \\
\hline & Male & $54(67.5 \%)$ \\
\hline \multirow[t]{4}{*}{ Smokinga } & Never-smokers & $9(11.25 \%)$ \\
\hline & Former smokers & $27(33.75 \%)$ \\
\hline & Current smokers & $34(42.5 \%)$ \\
\hline & NA & $10(12.5 \%)$ \\
\hline \multirow[t]{3}{*}{ Grading } & G1 & $8(10 \%)$ \\
\hline & G2 & $24(30 \%)$ \\
\hline & G3 & $48(60 \%)$ \\
\hline \multirow[t]{4}{*}{ Histology } & $\mathrm{ADC}$ & $27(33.75 \%)$ \\
\hline & $\mathrm{SCC}$ & $42(52.5 \%)$ \\
\hline & $\mathrm{LCC}$ & $9(11.25 \%)$ \\
\hline & ASC & $2(2.5 \%)$ \\
\hline \multirow[t]{3}{*}{ Lymph nodes metastasis } & Yes & $26(32.5 \%)$ \\
\hline & No & $53(66.3 \%)$ \\
\hline & NA & $1(1.25 \%)$ \\
\hline \multirow[t]{2}{*}{ Distant metastasis } & Yes & $0(0 \%)$ \\
\hline & No & $80(100 \%)$ \\
\hline \multirow[t]{2}{*}{$K R A S$} & Wild type & $67(83.75 \%)$ \\
\hline & Mutation $^{\mathrm{b}}$ & $13(16.25 \%)$ \\
\hline \multirow[t]{2}{*}{$E G F R$} & Wild type & $73(91.25 \%)$ \\
\hline & Mutation $^{\mathrm{c}}$ & $7(8.75 \%)$ \\
\hline \multirow[t]{3}{*}{$B R A F$} & Wild type & $77(96.25 \%)$ \\
\hline & Mutation V600E & $2(2.5 \%)$ \\
\hline & NA & $1(1.25 \%)$ \\
\hline
\end{tabular}

NA - not available; ADC - adenocarcinoma; SCC - squamous cell carcinoma; LCC - large cell carcinoma; ASC - adenosquamous carcinoma ${ }^{a}$ self- reported smoking status; ${ }^{b}$ includes G12A, G12C, G12D, G12S, $\mathrm{G} 12 \mathrm{~V}$ and G13D; ${ }^{\mathrm{c}}$ includes deletion of exon 19 , insertion in exon 20 and G719X

special stringent protocol was followed to avoid specimen contamination, including glove changes after DNA extraction of each sample, use of barrier pipette tips, and daily cleaning of all laboratory surfaces and equipment by DNA-ExitusPlus ${ }^{\mathrm{TM}}$ (AppliChem GmbH, Darmstadt, Germany). At least two no-template, control reaction mixtures (negative controls) were included in each run. All patient samples were analyzed in triplicate for the presence of HPV16, 18, 31, and 56 E6 DNA and GAPDH.

The cobas $^{\circledR} 4800$ HPV Test and PapilloCheck ${ }^{\circledR}$ HPVScreening were used, according to manufacturer's recommendations, to validate the qPCR HPV detection method described above. The cobas ${ }^{\circledR} 4800$ HPV Test detects HPV16, 18, and 12 other hrHPV genotypes (HPV31, $33,35,39,45,51,52,56,58,59,66$, and 68) in a pooled result $^{15}$, while the PapilloCheck ${ }^{\circledR}$ HPV-Screening provides genotyping information about $18 \mathrm{hrHPV}$ genotypes 
(HPV16, 18, 31, 33, 35, 39, 45, 51, 52, 53, 56, 58, 59, 66, 68, 70, 73, and 82) and 6 lrHPV genotypes (HPV6, 11, 40, 42, 43, and 44/55) ( ref. $\left.^{16}\right)$.

\section{Statistical analysis}

Sensitivity, specificity, concordance, and Cohen $\kappa$ values were calculated for data from all qPCR assays using $\mathrm{R}$ version 3.5.0 ( $\mathrm{R}$ Development Core Team, http://www.r-project.org, last accessed July 11, 2018). The $\operatorname{cobas}^{\circledR} 4800$ HPV Test results were used as references for HPV16 and HPV18 DNA, and the PapilloCheck ${ }^{\circledR}$ HPV-Screening results were used as references for all tested genotypes.

\section{RESULTS}

\section{Detection limit of the qPCR method}

The limit of detection (LOD) for the qPCR method was determined using plasmid DNA containing the genomes of HPV16, 18, 31, and 56. Serial dilutions of each type of HPV with concentrations ranging from 4 to 400000 copies of the HPV genome per reaction were analyzed in five replicates. The qPCR method reliably detected HPV genomes in samples that contained at least 4 copies of the E6 gene in HPV16, 18, and 31 genotypes, and 40 copies of the E6 gene in HPV56 (Table 3).

\section{Validation of the qPCR method}

A set of 402 cervical swabs was used to validate the novel qPCR method by evaluating its sensitivity and specificity. Two established detection methods, the Cobas ${ }^{\circledR}$

Table 2. Characteristics of HPV16, 18, 31, and 56 E6 and GAPDH primers/probes.

\begin{tabular}{|c|c|c|c|}
\hline Gene & Primer/probe & DNA sequence & Product size $(\mathrm{bp})$ \\
\hline \multirow[t]{3}{*}{ HPV16 $E 6^{\mathrm{a}}$} & Forward & 5'-GAGAACTGCAATGTTTCAGGACC-3' & 81 \\
\hline & Reverse & 5'-TGTATAGTTGTTTGCAGCTCTGTGC-3' & \\
\hline & Probe & BHQ1-CAGGAGCGACCCAGAAAGTTACCACAGTT-HEX & \\
\hline \multirow[t]{3}{*}{ HPV18 E6 } & Forward & 5'-CCCTACAAGCTACCTGATCT-3' & 100 \\
\hline & Reverse & 5'-CGGAACTGAACACTTCACTGCAAG-3' & \\
\hline & Probe & BHQ1-CCTCTGTAAGTTCCAATACTGTC-HEX & \\
\hline \multirow[t]{3}{*}{ HPV31 E6 } & Forward & 5'-CCATGGAGCCACAATTCA-3' & 134 \\
\hline & Reverse & 5'-CCTGCACCACTTGAGTGAGGTATT-3' & \\
\hline & Probe & BHQ1-CTCAGCACGTGTTAGTTCTT-HEX & \\
\hline \multirow[t]{3}{*}{ HPV56 E6 } & Forward & 5'-GCAGAAAGACCTCGGAAAT-3' & 95 \\
\hline & Reverse & 5'-CTCGGCATTGGAAATACCCTACGA-3' & \\
\hline & Probe & BHQ1-AACTGACCTTTGCAGTAGAC-HEX & \\
\hline \multirow[t]{3}{*}{$G A P D H$} & Forward & 5'-GAGTGAGTGGAAGACAGAATG-3' & 70 \\
\hline & Reverse & 5'-CAACTAGGATGGTGTGGCTCCC-3' & \\
\hline & Probe & BHQ1-GGGACACAAGGTTACCATATAC-CY5 & \\
\hline
\end{tabular}

${ }^{a}$ Primers for HPV16 detection were designed by Peitsaro et al. (ref. ${ }^{28}$ )

Table 3. Evaluation of the detection limit of the qPCR method.

\begin{tabular}{lllll}
\hline $\begin{array}{l}\text { HPV E6 gene copies/ } \\
\text { reaction }\end{array}$ & HPV16 $(95 \% \mathrm{CI})$ & HPV18 a $(95 \% \mathrm{CI})$ & HPV31 a $(95 \% \mathrm{CI})$ & HPV56 ${ }^{\mathrm{a}}(95 \% \mathrm{CI})$ \\
\hline $4 \times 10^{5}$ & $20.02(19.84-20.19)$ & $20.59(20.49-20.69)$ & $19.85(19.76-19.95)$ & $23.05(21.99-24.16)$ \\
$4 \times 10^{4}$ & $23.46(23.25-23.67)$ & $24.99(24.12-25.85)$ & $23.23(23.15-23.32)$ & $26.45(25.74-27.13)$ \\
$4 \times 10^{3}$ & $26.92(26.78-27.07)$ & $27.38(27.30-27.46)$ & $26.60(26.51-26.69)$ & $30.17(29.97-30.36)$ \\
$4 \times 10^{2}$ & $30.28(30.13-30.43)$ & $30.87(30.71-31.02)$ & $29.86(29.76-29.96)$ & $33.45(32.02-34.88)$ \\
$4 \times 10^{1}$ & $33.73(33.52-33.94)$ & $34.14(33.62-34.65)$ & $33.27(32.96-33.58)$ & $36.80(36.24-37.35)$ \\
$4 \times 10^{0}$ & $37.07(36.72-37.42)$ & $36.69(36.07-37.31)$ & $35.59(35.29-35.89)$ & - \\
\hline
\end{tabular}

CI - confidence intervals

${ }^{a}$ The average $C_{T}$ value of 5 dilution series analysed in duplicate 
Table 4. Specificity and sensitivity of qPCR amplifications of HPV16, 18, 31, and 56 E6 genes in samples of the validation set

\begin{tabular}{lcccccccc}
\hline Genotype & Tested method & Reference method & N & SE & SP & к (95\% CI $)$ & PPV & NPV \\
\hline HPV16 & qPCR & PapilloCheck & 182 & 0.993 & 0.735 & $0.801(0.683-0.919)$ & 0.942 & 0.962 \\
& & Cobas 4800 & 182 & 0.975 & 0.880 & $0.840(0.725-0.956)$ & 0.981 & 0.846 \\
HPV18 & qPCR & PapilloCheck & 60 & 0.958 & 0.639 & $0.551(0.357-0.745)$ & 0.639 & 0.958 \\
& & Cobas 4800 & 60 & 0.947 & 1.000 & $0.930(0.834-1.025)$ & 1.000 & 0.917 \\
HPV31 & qPCR & PapilloCheck & 93 & 0.985 & 0.880 & $0.888(0.780-0.995)$ & 0.957 & 0.957 \\
HPV56 & qPCR & PapilloCheck & 67 & 0.756 & 0.955 & $0.636(0.457-0.815)$ & 0.971 & 0.656 \\
\hline
\end{tabular}

SE- sensitivity; SP - specificity; $\mathrm{k}$ - Cohen's kappa coefficient; CI - confidence intervals; PPV- positive predictive value; NPV-negative predictive value

4800 HPV Test and the PapilloCheck ${ }^{\circledR}$ HPV-Screening, were used in parallel with the qPCR method to determine the presence of HPV16, 18, 31, and 56. The Cobas ${ }^{\circledR} 4800$ HPV Test provided specific genotyping information for HPV16 and HPV18 only, while the PapilloCheck ${ }^{\circledR}$ HPVScreening provided genotyping information for all tested genotypes. Therefore, the results of detection of HPV31 and HPV56 by the qPCR were compared to detection by the PapilloCheck ${ }^{\circledR}$ HPV-Screening results only. Samples were also tested for cross-reactivity with other HPV genotypes. Table 4 below presents the results of these comparisons.

For HPV16 detection, sensitivity and specificity levels of the qPCR were comparable to both the PapilloCheck ${ }^{\circledR}$ HPV-Screening and Cobas ${ }^{\circledR} 4800$ HPV Test. A comparison of the qPCR method with the PapilloCheck ${ }^{\circledR}$ HPVScreening showed sensitivity of $99.3 \%$ and specificity of $73.5 \%$. A comparison of the qPCR method with the Cobas $^{\circledR} 4800$ HPV Test showed sensitivity of $97.5 \%$ and specificity of $88.0 \%$.

For HPV18 detection, a comparison of the qPCR method with the PapilloCheck ${ }^{\circledR}$ HPV-Screening showed sensitivity of $95.8 \%$ and specificity of $63.9 \%$. A comparison of the qPCR method with the Cobas ${ }^{\circledR} 4800$ HPV Test showed sensitivity of $94.7 \%$ and specificity of $100 \%$.

For HPV31 and HPV56, a comparison of the qPCR method with the PapilloCheck ${ }^{\circledR}$ HPV-Screening showed sensitivity of $98.5 \%$ and $75.6 \%$, respectively, and specificity of $88.0 \%$ and $95.5 \%$, respectively.

No cross-reactivity was found in the qPCR detection method among any of the genotypes tested.

\section{HPV DNA detection in NSCLC}

All primary NSCLC samples were negative for HPV16, 18, 31, and 56 in both FFPE (80/80, 100\%) and FF samples $(80 / 80,100 \%)$. The amplification of the internal control, GAPDH, was successful in all tested DNA samples $\left(\mathrm{C}_{\mathrm{T}}<30\right)$. The qPCR was therefore successful in all 80 FFPE samples as well as all $80 \mathrm{FF}$ samples.

\section{DISCUSSION}

The results of this study confirm the low prevalence of hrHPV infection in primary NSCLC. HPV16, 18, 31, and 56 were not detected in this study population. This finding corroborates the findings of other studies con- ducted in Western European countries ${ }^{17-20}$. One recent large study involved lung cancer patients from six Central European countries, including patients from the Czech Republic (the number of participating Czech patients was unavailable). HPV16 DNA was detected in $6.6 \%$ of lung tumors in 290 of the available tissue samples. However, after testing the samples at the transcription level, none of the tumors expressed viral mRNA (ref. ${ }^{14}$ ).

In other studies, reports of the prevalence of HPV associated with lung tumors demonstrate extremely large heterogeneity, ranging from $0 \%$ to $78 \%$ (ref. ${ }^{13}$ ). HPV 16 and HPV18 were the most frequently detected genotypes in lung tumors, with high geographical variability $^{12}$. The highest prevalence of HPV16/18 was found in South/Central America, followed by Asia, North America, and Europe, with adjusted prevalence values of $22 \%, 5 \%, 4 \%$, and $3 \%$ respectively ${ }^{12}$. Geographical differences in the prevalence of HPV in lung tumor tissue could be associated with cultural variations in sexual behaviour, smoking habits, genetics, or environmental exposures $^{21,13}$.

High variability in HPV DNA prevalence could also be observed within a country. Chinese studies, for example, show HPV prevalence in China ranging from $8.4 \%$ to $73 \%$ $\left(\right.$ ref. $\left.^{22-24}\right)$. High rates of false positives could be contributing to the large variability in HPV prevalence. For this reason, extensive efforts should be made to avoid contamination during HPV DNA detection. Our results indicate that the stringent contamination precautions we took while conducting pre-PCR and PCR activities were sufficient for avoiding contamination. Moreover, the presence of HPV DNA does not signify an active HPV infection, and samples found positive for HPV DNA are frequently negative for HPV transcripts ${ }^{14,25}$. The measurement of viral E6/ E7 transcripts is widely considered the gold standard for detecting biologically-relevant HPV infection. If possible, expression levels of viral oncoproteins should be tested to establish the causal role of the HPV in lung carcinogenesis in HPV-positive lung tumors.

Unlike cervical cancer, the HPV viral load in lung cancer is very low, with less than one copy per cell ${ }^{26}$. However, like cervical cancer, HPV frequently integrates into the host genome, typically causing E2 gene disruption $^{26,27}$. In some studies, HPV infection may have been overlooked when the assay targeted the part of the HPV genome that is lost during integration. Thus, a sufficiently sensitive method for detecting a more appropriate HPV 
region is necessary to avoid false negatives. We designed a qPCR assay with a very low LOD to eliminate the likelihood of false negativities. This qPCR can detect up to 4 or 40 copies of HPV DNA per reaction, and amplifies the E6 HPV gene which is necessary for HPV-related cancer development and is, therefore, present during all clinically-relevant infections ${ }^{26}$.

DNA degradation usually occurs in FFPE samples, and these samples can produce false negative results. The quality of the DNA obtained from the samples for the qPCR HPV detection assay developed for this study, including DNA isolated from FFPE samples, was confirmed by a sufficient 260/280 ratio and successful amplification of internal control gene GAPDH. Moreover, both FF as well as FFPE samples from each patient were tested to detect any positive HPV DNA in a given patient that may have been missed if only FFPE samples were tested.

\section{CONCLUSION}

In conclusion, no HPV was detected in Czech patients with non-small cell lung cancer despite the use of a very sensitive qPCR test. As is consistent with other studies, no etiologic role of the hrHPV infection in the development of primary NSCLC was identified in the Czech population. Further investigation involving a larger number of lung cancer tissues is required to reach safe conclusions.

Acknowledgement: This work was supported by a grant, NPS I LO1304, from the Czech Ministry of Education, Youth and Sports.

The authors would like to thank Dr. Laimonis A. Laimins (Northwestern University, Feinberg School of Medicine, Chicago, USA) for providing of plasmid containing HPV31 genome and Dr. Jana Vrbkova for statistical analysis.

Author contributions: HJ, VK, RS: conceived and designed the experiment; HJ: performed the HPV analysis; JD: performed the $E G F R, K R A S, B R A F$ mutation analysis; $\mathrm{HJ}, \mathrm{VK}$ : analysed the data and wrote the manuscript; $\mathrm{MH}$ : final approval.

Conflict of interest statement: None declared.

Ethics approval and consent to participate: Study proposals were approved by the Ethics Committee of the Faculty of Medicine and Dentistry of Palacky University Olomouc and the Faculty Hospital in Olomouc (approval no. 122/11) in compliance with the Helsinki Declaration. Written informed consent for the use of collected samples for research was obtained from all study participants.

\section{REFERENCES}

1. Spyratos D, Zarogoulidis $P$, Porpodis $K$, Tsakiridis $K$, Machairiotis N, Katsikogiannis N, Kougioumtzi I, Dryllis G, Kallianos A, Rapti A, Li C, Zarogoulidis K. Occupational exposure and lung cancer. JThorac Dis 2013;5 Suppl 4:S440-S445.

2. Moore PS, Chang Y. Why do viruses cause cancer? Highlights of the first century of human tumour virology. Nat Rev Cancer 2010;10(12):878-89.
3. Gao G, Smith DI. Human Papillomavirus and the Development of Different Cancers. Cytogenet Genome Res 2016;150(3-4):185-93.

4. Leemans CR, Snijders PJF, Brakenhoff RH. The molecular landscape of head and neck cancer. Nat Rev Cancer 2018;18(5):269-82.

5. Katsenos S, Becker HD. Recurrent respiratory papillomatosis: a rare chronic disease, difficult to treat, with potential to lung cancer transformation: apropos of two cases and a brief literature review. Case Rep Oncol 2011;4(1):162-71.

6. Carifi M, Napolitano D, Morandi M, Dall'Olio D. Recurrent respiratory papillomatosis: current and future perspectives. Ther Clin Risk Manag 2015;11:731-8.

7. Syrjanen KJ. Condylomatous changes in neoplastic bronchial epithelium. Report of a case. Respiration 1979;38(5):299-304.

8. Rubel L, Reynolds RE. Cytologic description of squamous cell papilloma of the respiratory tract. Acta Cytol 1979;23(3):227-31.

9. Xiong WM, Xu QP, Li X, Xiao RD, Cai L, He F. The association between human papillomavirus infection and lung cancer: a system review and meta-analysis. Oncotarget 2017;8(56):96419-32.

10. Zhai K, Ding J, Shi HZ. HPV and lung cancer risk: a meta-analysis. J Clin Virol 2015;63:84-90.

11. Syrjanen K. Detection of human papillomavirus in lung cancer: systematic review and meta-analysis. Anticancer Res 2012;32(8):323550.

12. Ragin C, Obikoya-Malomo M, Kim S, Chen Z, Flores-Obando R, Gibbs D, Koriyama C, Aguayo F, Koshiol J, Caporaso NE, Carpagnano GE, Ciotti M, Dosaka-Akita H, Fukayama M, Goto A, Spandidos DA, Gorgoulis V, Heideman DA, van Boerdonk RA, Hiroshima K, Iwakawa R, Kastrinakis NG, Kinoshita I, Akiba S, Landi MT, Eugene LH, Wang JL, Mehra R, Khuri FR, Lim WT, Owonikoko TK, Ramalingam S, Sarchianaki E, Syrjanen K, Tsao MS, Sykes J, Hee SW, Yokota J, Zaravinos A, Taioli E. HPV-associated lung cancers: an international pooled analysis. Carcinogenesis 2014;35(6):1267-75.

13. Srinivasan M, Taioli E, Ragin CC. Human papillomavirus type 16 and 18 in primary lung cancers--a meta-analysis. Carcinogenesis 2009;30(10):1722-8.

14. Anantharaman D, Gheit T, Waterboer T, Halec G, Carreira C, AbediArdekani B, McKay-Chopin S, Zaridze D, Mukeria A, SzeszeniaDabrowska N, Lissowska J, Mates D, Janout V, Foretova L, Bencko V, Rudnai P, Fabianova E, Tjonneland A, Travis RC, Boeing H, Quiros JR, Johansson M, Krogh V, Bueno-de-Mesquita HB, Kotanidou A, Clavel-Chapelon F, Weiderpass E, Johansson M, Pawlita M, Scelo G, Tommasino M, Brennan P. No causal association identified for human papillomavirus infections in lung cancer. Cancer Res 2014;74(13):3525-34.

15. GmbH RD. Cobas 4800 HPV Test. Roche Molecular Systems Inc 2012

16. GmbH. PapilloCheck high-risk. Greiner Bio-One 2012

17. Koshiol J, Rotunno M, Gillison ML, Van Doorn LJ, Chaturvedi AK, Tarantini L, Song H, Quint WG, Struijk L, Goldstein AM, Hildesheim A, Taylor PR, Wacholder S, Bertazzi PA, Landi MT, Caporaso NE. Assessment of human papillomavirus in lung tumor tissue. J Natl Cancer Inst 2011;103(6):501-7.

18. Coissard CJ, Besson G, Polette MC, Monteau M, Birembaut PL, Clavel CE. Prevalence of human papillomaviruses in lung carcinomas: a study of 218 cases. Mod Pathol 2005;18(12):1606-9.

19. Galvan A, Noci S, Taverna F, Lombardo C, Franceschi S, Pastorino U, Dragani TA. Testing of human papillomavirus in lung cancer and non-tumor lung tissue. BMC Cancer 2012;12:512.

20. van Boerdonk RA, Daniels JM, Bloemena E, Krijgsman O, Steenbergen RD, Brakenhoff RH, Grunberg K, Ylstra B, Meijer CJ, Smit EF, Snijders PJ, Heideman DA. High-risk human papillomavirus-positive lung cancer: molecular evidence for a pattern of pulmonary metastasis. J Thorac Oncol 2013;8(6):711-8.

21. Cheng YW, Chiou HL, Sheu GT, Hsieh LL, Chen JT, Chen CY, Su JM, Lee $H$. The association of human papillomavirus 16/18 infection with lung cancer among nonsmoking Taiwanese women. Cancer Res 2001;61(7):2799-803.

22. Yu Y, Liu X, Yang Y, Zhao X, Xue J, Zhang W, Yang A. Effect of FHIT loss and p53 mutation on HPV-infected lung carcinoma development. Oncol Lett 2015;10(1):392-8.

23. Xu Y, Cheng B, Pan H, Wu A, Zhang L. [The Relationship between the Status of Human Papillomavirus 16/18 Infection and the Expression of $\mathrm{Bcl}-2$ and Bax in Squamous Cell Carcinomas of the Lung.]. Zhongguo Fei Ai Za Zhi 2009;12(8):849-52.

24. Xiong WM, He F, Xiao RD, Yu TT, Zhang X, Liu ZQ, Xu QP, Cai L. 
[Association between human papillomavirus infection and lung cancer]. Zhonghua Liu Xing Bing Xue Za Zhi 2016;37(12):1658-61.

25. Argyri E, Tsimplaki E, Marketos C, Politis G, Panotopoulou E. Investigating the role of human papillomavirus in lung cancer. Papillomavirus Res 2017;3:7-10.

26. de Freitas AC, Gurgel AP, de Lima EG, de Franca Sao MB, do Amaral CM. Human papillomavirus and lung cancinogenesis: an overview. J Cancer Res Clin Oncol 2016;142(12):2415-27.
27. Baba M, Castillo A, Koriyama C, Yanagi M, Matsumoto H, Natsugoe S, Shuyama KY, Khan N, Higashi M, Itoh T, Eizuru Y, Aikou T, Akiba S. Human papillomavirus is frequently detected in gefitinib-responsive lung adenocarcinomas. Oncol Rep 2010;23(4):1085-92.

28. Peitsaro $P$, Johansson B, Syrjanen S. Integrated human papillomavirus type 16 is frequently found in cervical cancer precursors as demonstrated by a novel quantitative real-time PCR technique. J Clin Microbiol 2002;40(3):886-91. 